DOI https://doi.org/10.30525/978-9934-26-183-1-7

\title{
FEATURES OF THE USE OF CATALYTIC CONVERTERS IN DUAL-USE TECHNOLOGIES FOR NEUTRALIZE TOXIC AGENTS
}

\author{
Karakurkchi H. V. \\ Doctor of Technical Sciences, Senior researcher, \\ Head of the Scientific and Methodological Department of Scientific \\ and Methodological Centre for Organization \\ and Coordination of Educational Activity \\ National Defense University of Ukraine named after Ivan Cherniakhovskyi \\ Kyiv, Ukraine \\ Sakhnenko M. D. \\ Doctor of Technical Sciences, Professor, \\ Head of the Department of Physical Chemistry \\ National Technical University "Kharkiv Polytechnic Institute" \\ Kharkiv, Ukraine \\ Korohodska A. M. \\ Doctor of Technical Sciences, Assosiated Professor, \\ Assosiated Professor at the Department of General and Inorganic Chemistry \\ National Technical University "Kharkiv Polytechnic Institute" \\ Kharkiv, Ukraine
}

The pollution of the environment with synthetic and man-made toxicants is one of the main problems of our time. This is due to the active economic activities of mankind and the growing number of man-made accidents at potentially dangerous objects (chemical and food industry enterprises, sewage treatment plants, etc.), wich occurring with uncontrolled leakage of toxic substances into the environment. As a result, there is a negative impact on the environment, living beings, raw materials and production processes.

This is especially dangerous for the safe operation of livelihoods and mobile and civilian and military vehicles, given the outdated fleet of existing filter ventilation systems of individual and collective protection systems. Therefore, it is important to create safe conditions for civilians and security and defense personnel and to reduce the impact of toxicants on the environment, in particular when using filter-ventilation systems on mobile facilities and long-term use systems. 
An effective approach to solving this problem is the use of catalytic converters for the disposal of toxic substances, both in civilian industries and for the needs of the defense industry. Their operation is based on the use of catalytic reactions that occur on the surface of the catalyst and provide neutralization of toxins to non-toxic substances [1].

In the general case, the catalysts are subject to requirements for corrosion resistance, mechanical strength, high catalytic activity, operation under conditions of high temperatures and pressures, the ability to regenerate. Heterooxide systems formed by plasma electrolytic oxidation (PEO) on valve metals (aluminum and titanium alloys) fully meet these requirements [2].

It should be noted that the production of catalytic materials is a multi-stage and long process, involving a significant number of individual technological operations [3]. In the formation of multicomponent compositions is quite difficult to manage the composition of catalytic materials in the process of their synthesis. In particular, the use of metal carriers requires increasing their specific surface area and applying auxiliary technological layers to ensure sufficient adhesion of the catalytic layer.

In the formation of heterooxide nanocomposites by the PEO method, it is possible to combine in one technological process the formation of a highly developed surface of the carrier material and the formation of a catalytically active layer, which is supplemented with oxides of the target components. The possibility of using the PEO method for the formation of composite oxide coatings on parts of complex shape, in particular on thin metal grids as carriers of the catalytic layer is the positive side. This technological form of the catalyst allows to increase the working surface area, accelerate the heating of the catalytic system to the operating temperature, and expand the temperature range of the catalyst.

The authors developed some functional nanocomposite coatings on aluminum and titanium alloys with a set of enhanced functional properties $[2,4]$.

It is proposed the use of complex electrolytes based on alkali metal diphosphates and the "decreasing power" mode with variation of current density to obtain nanocomposite coatings enriched with the target active ingredient. It is shown that the change in the component composition of the PEO working electrolyte allows the introduction of compounds of transition, noble, rare and scattered elements into the composition of the heterooxide surface layers. The formation process and the characteristics of the synthesized heterooxide layer can be controlled by varying the PEO parameters. 
The connections between conditions of formation of coatings, their structure and properties are established, algorithms of formation process planning of heterooxide coatings depending on structure of the processed material (alloys of various structure) are defined as a result of the conducted researches.

Based on experimental studies, variable technological schemes have been developed by forming heterooxide coatings with high content of active components and specified functional properties by plasma-electrolyte treatment of valve metal alloys (aluminum and titanium). Complex of operational and consumer properties of obtained coatings provides the efficiency of their application and long service life for the disposal of toxic agents.

An example of the practical implementation of the developed catalytic systems is the intra-cylinder environmental catalysis of internal combustion engines for civil and military use.

Laboratory and research and industrial studies [5] confirmed a reduction in $\mathrm{NO}_{\mathrm{x}}$ emissions within $10 \%$ and $\mathrm{CO}-15-18 \%$ and a reduction in hourly fuel consumption within 1-4\% for coatings synthesized on the piston of the internal combustion engine KamAZ-740.

Thus, by using modern achievements of electrochemical materials science in the synthesis of poly functional nanocomposite materials, the degree of protection of personnel and infrastructure is increased by equipping filter ventilation systems with catalytic converters to neutralize synthetic and manmade toxicants. Additional equipment of existing filter ventilation systems with catalytic converters for neutralization of synthetic and man-made toxins is considered promising. The practical implementation of the proposed technological approach corresponds to the priority areas of world science and technology and is aimed at creating a scientific basis for innovative dual-use technologies to strengthen defense capabilities and increase environmental security.

\section{References:}

1. Suib S. L. New and Future Developments in Catalysis: Catalysis for remediation and environmental concerns.Elsevier, 2013.618 p.

2. Karakurkchi A. V., Sakhnenko N. D., Ved M. V., Gorohivskiy A. S., Galak O. V., Menshov S. M., Matykin O. V. Cobalt and manganese oxide catalytic systems on valve metals in ecotechnologies. Promising Materials and Processes in Applied Electrochemistry : Monograph / editor-in-chief V S. Barsukov. Kyiv, 2017. P. 214-223. 
3. Ved MV., Sakhnenko N.D., Karakurkchi A.V., Yermolenko I.Yu. Electroplating and functional properties of Fe-Mo and Fe-Mo-W coatings. Issues of Chemistry and Chemical Technology. 2014. No 5-6. P. 53-60.

4. Sakhnenko M., Karakurkchi A., Galak A., Menshov S., Matykin O. Examining the formation and properties of $\mathrm{TiO}_{2}$ oxide coatings with metals of iron triad Eastern-European Journal of Enterprise Technologies. 2017. Vol. 2,No. 11(86). P. 4-10.

5. ParsadanovI. V., SakhnenkoM. D., KhyzhnyakV. O., Karakurkchi H. V. Improving the environmental performance of engines by intra-cylinder neutralization of toxic exhaust gases. Internal Combustion Engines. 2016. No 2. P. 63-67.

DOI https://doi.org/10.30525/978-9934-26-183-1-8

\title{
ОЦІНКА АНТРОПОГЕННОГО НАВАНТАЖЕННЯ НА ПРИКЛАДІ РІЧКИ АЛЬТА
}

\author{
Ковальська М. \\ студент \\ Національний медичний університет імен. О. О. Богомольия \\ м. Київ, Украӥна \\ Дзюбенко О. В. \\ кандидат біологічних наук \\ Університет Григорія Сковороди в Переяславі \\ Новікова І. П. \\ асистент \\ Національний медичний університет імені О. О. Богомольия \\ м. Київ, Украӥна
}

В останні десятиріччя спостерігається посилення негативного впливу на якісний стан водних ресурсів таких чинників як зміна клімату, активне землекористування, антропогенне та техногенне забруднення води, зростаюче водоспоживання [1, с. 50]. Велику кількість шкідливих речовин та стічних вод, отримує річка Альта. Природні водотоки зазнають значного антропогенного навантаження у першу чергу за рахунок поверхневого стоку з сільськогосподарських територій, а також 